\title{
Longitudinal distribution and seasonality of macroalgae in a subtropical stream impacted by organic pollution
}

\author{
Distribuição longitudinal e sazonalidade de macroalgas \\ em um riacho subtropical impactado por poluição orgânica
}

Cleto Kaveski Peres, Ciro Cesar Zanini Branco, Rogério Antonio Krupek and José Celso Rocha
Departamento de Ciências Biológicas, Universidade Estadual Paulista - UNESP,
Av. Dom Antônio, 2100, CEP 19806-900, Assis, SP, Brazil
e-mail: cletoperes@yahoo.com.br, czbranco@assis.unesp.br,
rogeriokrupek@yahoo.com.br, jcelso@assis.unesp.br

\begin{abstract}
Aim: This study was carried out to assess longitudinal and temporal distribution and the effects of organic pollution on macroalgal communities in a subtropical stream; Methods: The occurrence and percent cover of stream macroalgae were investigated during seasonal period in four sampling sites along the course of the Cascavel Stream, in Paraná State, subtropical area of Brazil. Sampling sites were randomly chosen; however, their location in relation to urban organic pollution sources was taken into consideration. Besides, several stream variables usually related to organic pollution in aquatic ecosystems were measured; Results: Eleven macroalgal taxa were found during the samplings. Chlorophyta was the prevailing division (4 species or $36.3 \%$ of the total richness), followed by Cyanophyta and Rhodophyta (3 or 27.3\%) and Heterokontophyta (1 or $9.1 \%$ ). Analysis of variance (ANOVA) showed no significant differences in species diversity, percent cover and diversity index among seasons or the sampling sites. In addition, species diversity was not correlated with any environmental variable in particular. On the other hand, the relative composition of the stream macroalgal communities showed wide spatial and temporal variation. Thus, Chlorophyta had higher values of richness and percent cover in sampling site with higher levels of organic pollution, while Rhodophyta was never found in this segment. Taking seasonality into consideration, Chlorophyta had higher values of percent cover in winter, but Rhodophyta and Cyanophyta in spring and fall, respectively; Conclusions: In general terms, in this study macroalgal community structures were slightly affected by organic pollution, mainly by increase in richness and percent cover of Chlorophyta associated with the absence of Rhodophyta in the most polluted sampling site. The analysis of the richness throughout the stretch of the stream showed that the highest values were found in the intermediate part, being partly in accordance with the RCC (River Continuum Concept).
\end{abstract}

Keywords: local-scale variation, Brazil, anthropic impact, environmental assessment.

Resumo: Objetivo: O presente estudo foi desenvolvido com o objetivo de avaliar a distribuição longitudinal e temporal e o efeito da poluição orgânica em comunidades de macroalgas em um riacho subtropical; Métodos: A presença e a cobertura percentual das macroalgas foram investigadas durante um período sazonal em quatro pontos de amostragem ao longo do perfil longitudinal do rio Cascavel, Estado do Paraná, região subtropical do Brasil. Os pontos de amostragem foram aleatoriamente escolhidos, porém as suas localizaçôes em relação às fontes de poluição orgânica urbanas foram consideradas. Em adição, diversas variáveis ambientais comumente relacionadas à poluição orgânica em ecossistemas aquáticos foram mensuradas; Resultados: Durante as amostragens foram encontrados 11 táxons macroalgais. Chlorophyta foi a divisão predominante (4 espécies ou 36,3\% da riqueza total), seguida por Cyanophyta e Rhodophyta (3 ou 27,3\%) e Heterokontophyta (1 ou 9,1\% do total). A Análise de variância (ANOVA) revelou que não existiram diferenças significativas nos valores de diversidade de espécies, cobertura percentual e índice de diversidade entre as estaçóes do ano ou entre os pontos de amostragem. Além disso, a diversidade de espécies não se correlacionou com nenhuma variável ambiental em particular. Por outro lado, a composição relativa da comunidade de macroalgas mostrou ampla variação espacial e temporal. Assim, Chlorophyta registrou maiores valores de riqueza e cobertura percentual no ponto de amostragem com maior nível de poluição orgânica, enquanto Rhodophyta não foi encontrada neste segmento. 
Chlorophyta teve o maior valor de cobertura percentual no inverno, ao passo que Rhodophyta e Cyanophyta na primavera e no outono, respectivamente; Conclusóes: De modo geral, no presente estudo as comunidades de macroalgas foram levemente influenciadas pela poluição orgânica, particularmente pelo aumento da riqueza e cobertura percentual de Chlorophyta associado com a ausência de Rhodophyta no segmento de maior nível de poluição. Em adição, a análise da riqueza no perfil longitudinal mostrou que os maiores valores foram encontrados na região intermediária, estando parcialmente de acordo com o RCC (Conceito do Contínuo Fluvial).

Palavras-chave: variação em escala local, Brasil, impacto antropogênico, avaliação ambiental.

\section{Introduction}

Throughout the course of lotic systems, natural changes in environmental characteristics such as riparian vegetation, flow stability, relative proportion of substrate types, among other things, have been described as determining factors in the population dynamics of aquatic organisms (Vannote et al., 1980; Allan and Castillo, 2007). However, several human activities can produce significant nonnatural changes in such ecosystems (e.g., reduction of riparian vegetation, introduction of exotic species, habitat homogenization, increase of chemical and organic pollution) and, consequently, negative impacts on the associated aquatic biota, particularly on those with benthic behavior (Camargo and Jimenez, 2007).

Taking into consideration the vulnerability of lotic habitats (Smith and Petrere Jr., 2000), studies focusing on the impact of anthropic interference are strongly recommended in order to favor appropriate management and to ensure that ecological quality could be restored in such environments (Strieder et al., 2006).

From that perspective, many research works have been carried out aiming at assessing the effects of pollution on stream algae (e.g., Vis et al., 1998; Hill et al., 2000, Fellows et al., 2006; Camargo and Jimenez, 2007). In general, despite the lack of information, it is known that chemical and organic pollution can affect the algal community structure, causing changes, for instance, in taxonomic composition, dominance of one or of a few species and, even individual species bloom (Rosenberg and Resh, 1993; Vidotti and Rollemberg, 2004). However, almost all of those studies used benthic microalgae as target biota, diatoms in particular, and few information are available concerning macroalgal assemblages (e.g., Dell'uomo, 1991; Necchi Jr. et al., 1994; Branco and Pereira, 2002).

According to Biggs (1989) the best reference to undertake environmental assessment is the one provided by the community as a whole. Within such a context, the awareness of the effects caused by pollution on several aquatic organisms, macroalgae included, becomes relevant to a better interpretation and development of index for lotic environment ecological quality monitoring.

Many investigations focusing general ecological patterns and, in particular, seasonal distribution of macroalgal communities have been carried out worldwide (e.g., Sheath and Cole, 1992; Branco and Necchi Jr., 1996; Necchi Jr. et al., 2000; Hu and Xie, 2006). However, in Brazil, only two papers are found in which macroalgal communities are analyzed concerning their response to different levels of organic pollution in lotic environments. Necchi Jr. et al. (1994) analyzed the use of macroalgae to assess organic pollution in the Preto River and Branco and Pereira (2002) assessed the potential use of macroalgae as bioindicators in the Claro River. Both studies were carried out in streams located in Northwestern São Paulo State, in a Brazilian tropical area.

In the subtropical area of Brazil, research works focusing macroalgal communities in lotic environments affected by anthropic action are nonexistent. Thus, we carried out a field monitoring to describe the longitudinal distribution and seasonalilty of macroalgae, in order to assess the possible effects of organic pollution on these assemblages.

\section{Material and Methods}

This study was carried out in the Cascavel Stream, a lotic system located in the third plateau of Paraná State (Maack, 1981). The natural riparian vegetation along the stream was mainly composed by grasslands and mixed ombrophilous forest (Roderjan et al., 2002), however, the area has been affected by anthropic pressure and the riparian vegetation has been severely degraded. This stream is the main water course crossing the urban area of 
Guarapuava, a town of about 150,000 inhabitants in Paraná State, southern Brazil.

Four stretches along the Cascavel Stream were sampled once in each season from May/2004 to February/2005. A brief description and location of each stretch sampled in the stream is shown in Table 1. The sampling sites were randomly chosen, but their location within the urban area, mainly organic pollution sources, was taken into consideration.

Water temperature, specific conductance, $\mathrm{pH}$, and oxygen saturation were taken using the water analyzer Consort C535. Turbidity was measured by the portable turbidimeter Hach 2100P. Flow velocity was checked by the mechanical flowmeter General Oceanics 2030R, while depth and width were measured by a ruler. Local rainfall data were collected at the rainfall experiment station of the Instituto Agronômico do Paraná (IAPAR), located in the intermediate part of the Cascavel Stream basin.

Besides, biochemical oxygen demand (BOD) was determined by dilution and incubation method at $20{ }^{\circ} \mathrm{C}$ for five days (APHA, 1998). Chemical oxygen demand (COD) was determined by the method of dichromate digestion in an acid environment and titration with ferrous sulfate (APHA, 1998). Phosphate and ammoniacal nitrogen were determined by photometric method using a Spectroquant Nova 60 spectrophotometer, with specific reagents. Total and fecal coliforms were analyzed by filter membrane method, by means of a previous dilution of the sample with 24 hours incubation at $35.5^{\circ} \mathrm{C}$ and posterior counting (APHA, 1998).

The investigation of macroalgal communities in all sampling sites was carried out within a permanently established $10 \mathrm{~m}$ cross-transect (Necchi Jr. et al., 1995). For presence and estimation of percent cover of each macroalgal species the transect length was divided into 10 equal parts by a rope marked at $1 \mathrm{~m}$ intervals, which was extended along the riverbank (Necchi Jr., 1993; Necchi Jr. and Pascoaloto, 1993; Necchi Jr. et al., 1994). Percent cover on the stream bottom was calculated by visual analysis (Sheath and Burkholder, 1985; Borges and Necchi Jr., 2006), for each $1 \mathrm{~m}$ interval and averaged for the whole $10 \mathrm{~m}$ transect (Necchi Jr. and Pascoaloto, 1993).

Shannon-Wiener diversity index (Krebs, 1989) was calculated for each sampling site and season as described by Borges and Necchi Jr. (2006) (Equation 1):

$\mathrm{H}^{\prime}=\Sigma \mathrm{s}\left(\mathrm{pi} \log _{10}\right.$ pi $)$

where: $\mathrm{pi}=$ proportion (abundance $=$ percent cover) of species i within community; $s=$ number of species in the community.

The analysis of variance (ANOVA) was made to test whether there were significant differences among sampling sites and seasons, regarding richness, percent cover, and diversity. Therefore, Pearson's $r$ Correlation was applied to find possible correlations between biotic and abiotic variables. Statistic analyses were carried out by using the Past Statistic Pack (Hammer et al., 2001).

\section{Results}

\subsection{Characterization of environmental variables}

Temperature, $\mathrm{pH}$, and depth presented similar values among stream stretches while specific conductance, total and fecal coliforms and flow velocity showed very variable values (Table 2 ). The average values of BOD, COD, phosphate, and ammoniacal nitrogen increased from the upper to the lower parts of the stream; however, as a rule, the values found in $\mathrm{P} 3$ were higher than the ones reported in P4 (Table 2). Oxygen saturation presented the lowest average values in $\mathrm{P} 3$ and

Table 1. Location of sampling sites in the Cascavel Stream, Guarapuava, Paraná State.

\begin{tabular}{|c|c|}
\hline Sites & Localization and principal characteristics \\
\hline $\mathrm{P} 1$ & $\begin{array}{l}\text { It is the most upstream sampling site, localized before urban area and receives few amount of effluents from farming } \\
\text { activities, } 25^{\circ} 20^{\prime} 49^{\prime} \text { S and } 51^{\circ} 27^{\prime} 38^{\prime} \text { 'W; A: } 1,059 \mathrm{~m} \text {; MW: } 2.5 \mathrm{~m} \text {; MD: } 28 \mathrm{~cm} \text {; S: bedrock and boulders; SH: open. }\end{array}$ \\
\hline P2 & $\begin{array}{l}\text { This sampling site is localized in the board of the urban area and receives few amount of raw domestic sewage, } \\
25^{\circ} 22^{\prime} 08^{\prime \prime} \mathrm{S} \text { and } 51^{\circ} 29^{\prime} 35^{\prime \prime} \mathrm{W} ; \mathrm{A}: 1,017 \mathrm{~m} \text {; MW: } 3.0 \mathrm{~m} \text {; MD: } 25 \mathrm{~cm} \text {; S: boulders and macrophytes; } \mathrm{SH} \text { : open. }\end{array}$ \\
\hline P3 & $\begin{array}{l}\text { This sampling site is located in the middle of the urban area and receives great amounts of raw domestic sewage and } \\
\text { the final residues from sewage treatment plant processes, } 25^{\circ} 23^{\prime} 44^{\prime \prime} \mathrm{S} \text { and } 51^{\circ} 30^{\prime} 12^{\prime \prime} \mathrm{W} ; \mathrm{A}: 1,011 \mathrm{~m} \text {; MW: } 4.0 \mathrm{~m} \text {; } \\
\text { MD: } 29 \mathrm{~cm} \text {; S: boulders, pebbles and some macrophytes; } \mathrm{SH} \text { : open. }\end{array}$ \\
\hline P4 & $\begin{array}{l}\text { It is the most downstream sampling site, localized after the urban area, } 25^{\circ} 25^{\prime} 40^{\prime \prime} \mathrm{S} \text { and } 51^{\circ} 30^{\prime} 25^{\prime \prime} \mathrm{W} ; \mathrm{A}: 929 \mathrm{~m} \text {; } \\
\text { MW: } 6.0 \mathrm{~m} \text {; MD: } 27 \mathrm{~cm} \text {; S: boulders and sand/clay; SH: partly shaded. }\end{array}$ \\
\hline
\end{tabular}

A: altitude; MW: mean width; MD: mean depth; S: substrate; and SH: shading. 
turbidity increased continuously from site P1 to site P4 (Table 2).

Concerning seasons, temperature presented higher values in summer and spring, while $\mathrm{pH}$ in spring, turbidity in summer and phosphate and specific conductivity in winter. Total and fecal coliforms presented higher values in winter and summer, while oxygen saturation, flow velocity, and depth in fall and spring. BOD, COD, and ammoniacal nitrogen showed no clear temporal pattern.

Spring and fall had the highest values of accumulated precipitation in the last 15 and 30 days prior to the sampling dates, respectively, while summer had the highest value in the last 7 days (Figure 1). Winter showed the lowest value of accumulated precipitation in the three periods here analyzed (7, 15 and 30 days).

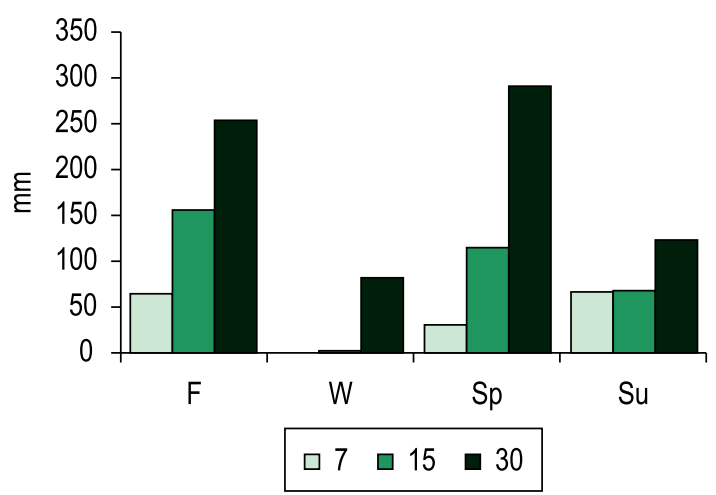

Figure 1. Precipitation accumulated values in the last 7,15 and 30 days before each sampling in the four seasons. $\mathrm{F}=$ Fall, $\mathrm{W}=$ Winter, $\mathrm{Sp}=$ Spring and, $\mathrm{Su}=$ Summer.

\subsection{Composition of macroalgal communities}

Eleven taxa were found during the samplings, belonging to four algae divisions (Table 3). Chlorophyta was the predominant division with $4 \operatorname{taxa}(36.3 \%$ of the total), followed by Cyanophyta and Rhodophyta with 3 taxa each $(27.3 \%)$ and Heterokontophyta with only 1 taxon (9.1\%). In site P1 the occurrence of Chlorophyta was not observed, while site P3 presented the prevalence of that algae division and the absence of Rhodophyta. Cyanophyta occurred in all sampling sites and Heterokontophyta, with only one taxon, was collected in P2 and P4.

Concerning the total richness by stream stretch, site P2 had the highest value (6 taxa), followed by sites P3 and P4 (4 taxa each) and site P1 (3 taxa). Six taxa $(54.5 \%$ of the total) were found in only one sampling site. The total richness by season revealed spring with the highest value with 7 taxa, followed by summer with 6 , fall with 5 and winter with 4 . Seven taxa $(63.6 \%$ of the total) were restricted to only one season.

The best distributed species was the Phormidium autumnale present in sampling sites $\mathrm{P} 2, \mathrm{P} 3$ and $\mathrm{P} 4$. Even though it was present in three sampling sites, this species was found only in fall and spring. Phormidium retzii and Kumanoa ambigua, in spite of being found in only two sampling sites, were collected in the four seasons of the year. Tolypothrix distorta, the only heterocytous Cyanophyta identified in the Cascavel Stream, was only observed in site P1, the sampling site with the lowest pollution level. On the other hand, the filamentous green algae Schizomeris leiblenii was exclusively identified in site P3.

Table 2. Environmental variable values (mean \pm standard-deviation) during the study period in the four sampling sites in Cascavel Stream, Guarapuava, Paraná State.

\begin{tabular}{|c|c|c|c|c|}
\hline & $\mathrm{P} 1$ & $\mathrm{P} 2$ & P3 & P4 \\
\hline Temperature $\left({ }^{\circ} \mathrm{C}\right)$ & $17.8 \pm 3.1$ & $18.6 \pm 4.4$ & $18.4 \pm 5.0$ & $18.0 \pm 5.8$ \\
\hline $\mathrm{pH}$ & $6.95 \pm 0.46$ & $6.74 \pm 0.56$ & $6.73 \pm 0.37$ & $7.22 \pm 0.31$ \\
\hline Specific conductance $\left(\mu \mathrm{S} . \mathrm{cm}^{-1}\right)$ & $162 \pm 162$ & $78 \pm 63$ & $195 \pm 185$ & $156 \pm 128$ \\
\hline Turbidity (NTU) & $7.9 \pm 3.7$ & $18.7 \pm 21.2$ & $19.7 \pm 25.2$ & $35.3 \pm 42.6$ \\
\hline Oxygen saturation (\%) & $60 \pm 11$ & $69 \pm 10$ & $43 \pm 16$ & $78 \pm 11$ \\
\hline Total coliforms (ufc. $100 \mathrm{~mL}^{-1}$ ) & $4225 \pm 4867$ & $9925 \pm 6142$ & $8525 \pm 8244$ & $10950 \pm 6361$ \\
\hline Fecal coliforms (ufc. $100 \mathrm{~mL}^{-1}$ ) & $3950 \pm 5190$ & $8700 \pm 6863$ & $6750 \pm 4266$ & $10025 \pm 7281$ \\
\hline $\mathrm{BOD}\left(\mathrm{mgO}_{2} \cdot \mathrm{L}^{-1}\right)$ & $3.81 \pm 1.19$ & $6.11 \pm 2.08$ & $26.42 \pm 24.72$ & $11.90 \pm 5.32$ \\
\hline $\operatorname{COD}\left(m g \cdot L^{-1}\right)$ & $29.68 \pm 19.27$ & $39,52 \pm 20.59$ & $50.96 \pm 40.66$ & $23.83 \pm 8.10$ \\
\hline Phosphate (mg. $\left.\mathrm{L}^{-1}\right)$ & $0.05 \pm 0.05$ & $0.06 \pm 0.05$ & $0.11 \pm 0.11$ & $0.07 \pm 0.07$ \\
\hline Ammoniacal nitrogen (mg. $\mathrm{L}^{-1}$ ) & $0.07 \pm 0.02$ & $0.06 \pm 0.02$ & $0.63 \pm 0.84$ & $0.59 \pm 0.78$ \\
\hline Current velocity $\left(\mathrm{cm} \cdot \mathrm{s}^{-1}\right)$ & $88.6 \pm 32.0$ & $117.0 \pm 30.9$ & $94.6 \pm 18.5$ & $68.7 \pm 5.1$ \\
\hline
\end{tabular}


Table 3. Occurrence of macroalgal species by sampling site and season in the Cascavel Stream, Guarapuava, Paraná State.

\begin{tabular}{|c|c|c|c|c|}
\hline Macroalgae taxa/sampling sites & P1 & P2 & P3 & P4 \\
\hline \multicolumn{5}{|l|}{ Cyanophyta } \\
\hline Phormidium autumnale (Agardh) Gomont & - & $\mathrm{F}$ & F Sp & F Sp \\
\hline P. retzii Gomont & W Sp Su & F W Sp & - & - \\
\hline Tolypothrix distorta Bornet et Flahault & $\mathrm{F}$ & - & - & - \\
\hline \multicolumn{5}{|l|}{ Chlorophyta } \\
\hline Cladophora glomerata (L.) Kützing & - & - & Su & - \\
\hline Rhizoclonium hieroglyphicum (C. Ag.) Kützing & - & - & - & $\mathrm{Su}$ \\
\hline Schizomeris leiblenii Kützing & - & - & F Sp Su & - \\
\hline Stigeoclonium amoenum Kuetzing & - & W & W Sp & - \\
\hline \multicolumn{5}{|l|}{ Heterokontophyta } \\
\hline Vaucheria sp. & - & Sp & - & W \\
\hline \multicolumn{5}{|l|}{ Rhodophyta } \\
\hline $\begin{array}{l}\text { Kumanoa ambigua (Mont.) } \\
\text { Entwisle, Vis, Chiasson, Necchi Jr. et Sherwood }\end{array}$ & Su & W F Sp Su & - & - \\
\hline $\begin{array}{l}\text { Batrachospermum puiggarianum } \\
\text { Grunow in Wittrock and Nordstedt }\end{array}$ & - & W Sp & - & - \\
\hline B. sp. & - & - & - & Su \\
\hline
\end{tabular}

$\mathrm{F}=$ Fall, $\mathrm{W}=$ Winter, $\mathrm{Sp}=$ Spring and $\mathrm{Su}=$ Summer .

\subsection{Longitudinal distribution and seasonal variation of macroalgal communities}

The species richness by sampling site ranged from 1 to 4 taxa and it was not correlated with any physical and chemical variable. The ShannonWiener Diversity Index ranged from 0 to 0.47 and it was not correlated with any physical and chemical variable either. The percent cover ranged between 0.5 to $5.3 \%$ of the streambed and was negatively correlated with $\mathrm{pH}(\mathrm{r}=-0.56, \mathrm{p}<0.05)$ and positively correlated with COD $(r=0.61$, $\mathrm{p}<0.05)$.

The ANOVA carried out among the sampling sites showed that there were significant differences in richness $(\mathrm{F}=3.47, \mathrm{p}=0.05)$; however, such a difference was observed neither in the percent cover values $(\mathrm{F}=1.30, \mathrm{p}=0.32)$ nor in the ShannonWiener Diversity Index $(F=1.96, p=0.17)$. The same test conducted among the seasons showed that there were no significant differences in richness $(\mathrm{F}=0.18, \mathrm{p}=0.91)$, percent cover $(\mathrm{F}=0.72$, $\mathrm{p}=0.56)$ or Shannon-Wiener Diversity Index $(\mathrm{F}=0.30, \mathrm{p}=0.83)$.

Concerning the global species number (Figure 2), the intermediate part of the stream (particularly sampling site P2) had the highest value of richness. Regarding algal divisions, variation in species number along the course of the stream was similar among Cyanophyta, Rhodophyta and Heterokontophyta, which generally had the lowest values in site P3. However, Chlorophyta showed a
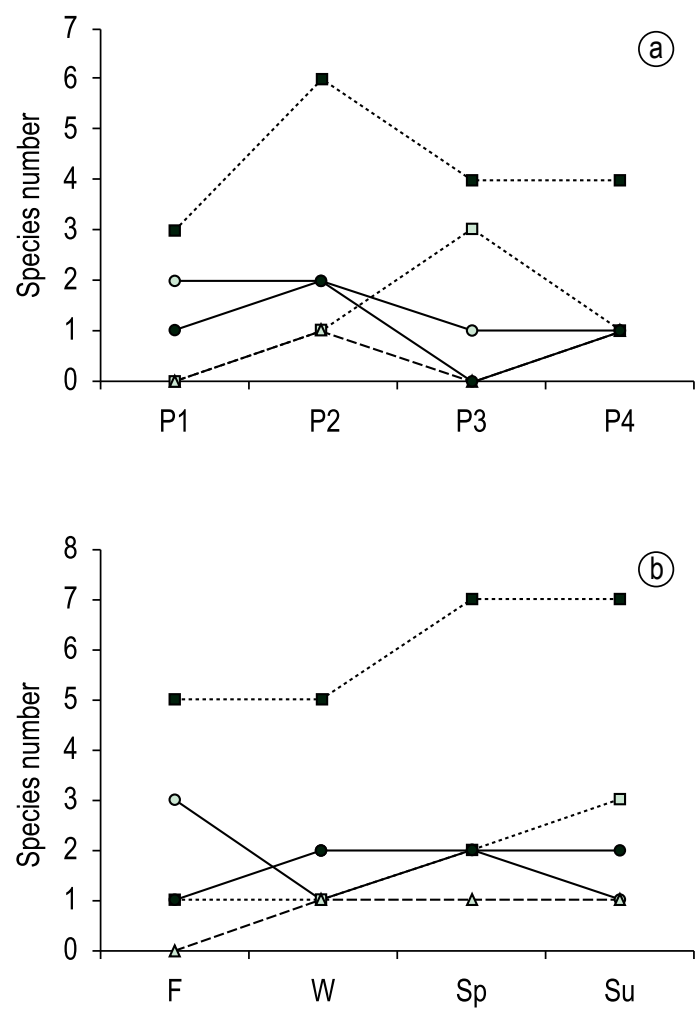

$\multimap-$ Cyanophyta $\quad$-.-- Chlorophyta
- - Heterokontophyta $\rightarrow$ - Rhodophyta $\quad$-... Total

Figure 2. Richness in macroalgal division (a) in the sampling sites and (b) seasons in the Cascavel Stream, Guarapuava, Paraná State. F $=$ Fall, $W=$ Winter, $\mathrm{Sp}=$ Spring and, $\mathrm{Su}=$ Summer. 
different pattern with the highest species number in site P3. In relation to the investigated seasons, the global species number showed the highest values in spring and summer (Figure 2). The species richness of Rhodophyta and Heterokonthophyta showed slight variations among seasons, while in the case of Cyanophyta the highest values were observed in fall and Chlorophyta in summer.

Similar to species richness, the percent cover of macroalgal communities (Figure 3) also showed the highest value in the intermediate part of the stream (site P2), seeing that Rhodophyta was the division which most contributed to this pattern. Cyanophyta showed higher percent cover in site P1 and Chlorophyta in site P3. The percent cover of macroalgal communities presented a higher global value in winter. Cyanophyta had higher values in fall, while Chlorophyta in winter and Rhodophyta in spring and summer.

Cyanophyta percent cover was negatively correlated with total coliforms $(\mathrm{r}=-0.59, \mathrm{p}<0.05)$, fecal coliforms $(\mathrm{r}=-0.55, \mathrm{p}<0.05)$, and ammoniacal
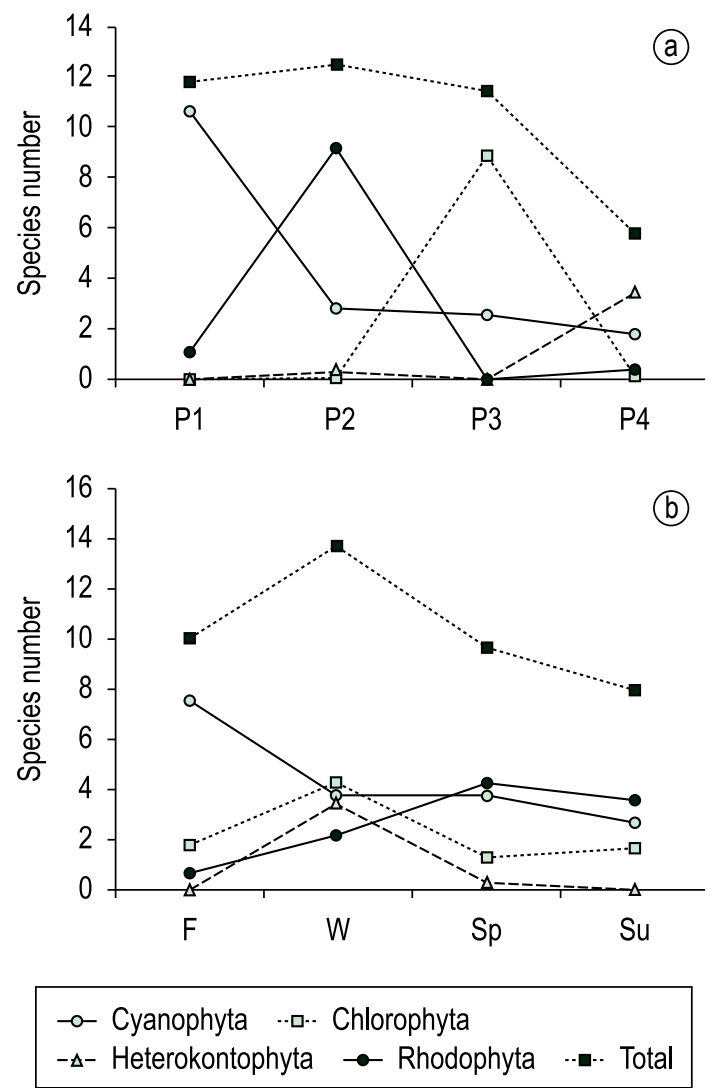

Figure 3. Macroalgal percent cover (a) in the sampling sites and (b) seasons in the Cascavel Stream, Guarapuava, Paraná State. $F=$ Fall, $W=$ Winter, $S p=$ Spring and, $\mathrm{Su}=$ Summer. nitrogen $(\mathrm{r}=-0.58, \mathrm{p}<0.05)$, while Chlorophyta percent cover was negatively correlated with oxygen saturation $(\mathrm{r}=-0.73, \mathrm{p}<0.01)$ and positively with $\operatorname{BOD}(\mathrm{r}=0.60, \mathrm{p}<0.05), \mathrm{COD}(\mathrm{r}=0.65, \mathrm{p}<0.05)$, phosphate $(\mathrm{r}=0.60, \mathrm{p}<0.05)$, and ammoniacal nitrogen $(r=0.59, p<0.05)$. On the other hand, Rhodophyta percent cover was not correlated with any physical and chemical variables. No correlations were found among biological variables (richness, percent cover, and diversity index) and accumulated precipitation ( 7,15 or 30 days).

\section{Discussion}

The wide variation of water temperature among the sampling sites and the seasons, and the $\mathrm{pH}$ values always close to neutral are probably due to the fact that the studied area is located in a subtropical region. Branco et al. (2009b), in a seasonal study of macroalgal communities in a nearby basin, found similar values for those two variables, indicating to be, actually, characteristic of this subtropical region.

The high values of specific conductance, BOD, COD, phosphate, and ammoniacal nitrogen observed in the Cascavel Stream are compatible with those found in studies carried out in other streams filled with organic pollution (e.g., Necchi Jr. et al., 1994; Branco and Pereira, 2002). The results clearly showed that the variables related to organic pollution had the highest values in site $\mathrm{P} 3$, while to oxygen saturation it was the lowest one. Such results confirm that this sampling site presented the highest levels of organic pollution in the stretch of the Cascavel Stream. The decrease in values of those variables in site $\mathrm{P} 4$ showed a possible depuration process along the stream. Similar results were found by Necchi Jr. et al. (1994) in Preto River.

Seasonal variations in values of specific conductance, turbidity, total and fecal coliforms, BOD, COD, phosphate, ammoniacal nitrogen, and oxygen saturation suggest a direct influence of rainfall on such variables. Probably a dilution effect caused by heavy rainfall can explain those data.

The number of taxa found during the study can be considered low when compared to similar research works (31 taxa in Branco and Pereira, 2002; and 21 taxa in Necchi Jr. et al., 1994). Hu and Xie (2006) analyzing the macroalgal communities of a Chinese river with identical sampling effort found 42 taxa, making clear the poor species richness observed in the Cascavel Stream.

The quantitative dominance of Chlorophyta division agrees with most of the studies dealing 
with macroalgae (Necchi Jr. et al., 1991; 1994; Sheath and Cole, 1992; Hu and Xie, 2006). Chlorophyta as the dominant algal group was also found in mid-western Paraná State (Branco et al., 2009a); however, some studies carried out in less disturbed areas have reported the Cyanophyta as the best represented division (Krupek et al., 2007; Peres et al., 2008).

Species richness, percent cover, and diversity index values by sampling site were very similar to those found in streams of Southern Brazil (e.g., Krupek et al., 2007; Peres et al., 2008; Branco et al., 2009a), but smaller than the ones reported in streams of São Paulo State (e.g., Necchi Jr., 1993; Necchi Jr. et al., 1994; Branco and Necchi Jr., 1996; Necchi Jr. et al., 2000) and in other areas around the world (e.g., Sheath et al., 1986; 1989; Sheath and Cole, 1992; Vis et al., 1994; Hu and Xie, 2006).

The highest values in species richness found in the middle part of the Cascavel Stream (site P2) are similar to the ones reported by Necchi Jr. and Moreira (1995) in a study of longitudinal distribution of macroalgal communities. In addition, this result is apparently in accordance with the River Continuum Concept (RCC, Vannote et al. 1980) which predicted that richness will be the lowest in headwaters, will increase in the middle parts and will decline in higher-order stretches. However, according to RCC, the prospective increase in richness in $\mathrm{P} 3$ was not observed. This fact probably occurred because this sampling site showed the strongest organic pollution level among all stretches investigated, making this stream segment particularly unsuitable for the development of a more diverse community (Necchi Jr. et al., 1994; Branco and Pereira, 2002).

The lack of significant differences in richness, percent cover and diversity index values among seasons is in contradiction with most of the seasonal dynamic investigations carried out in Brazil. Almost all studies of this kind point to rainfall as the main driving factor of seasonal fluctuation of macroalgal communities (e.g., Necchi Jr. and Pascoaloto, 1993; Branco and Necchi Jr., 1997; Branco and Pereira, 2002).

In opposition to Cyanophyta and Rhodophyta, the highest number of species of Chlorophyta was reported in P3. Branco and Pereira (2002) showed that in stretches with higher levels of pollution, Chlorophyta appeared as the division with the highest number of species, while Cyanophyta presented reduced values. Similar to species richness, percent cover revealed an expressive reduction of
Cyanophyta and a visible increase of Chlorophyta in the sampling site P3. These results, in association with the correlation observed among percent cover of Chlorophyta and BOD, COD, phosphate, ammoniacal nitrogen, and oxygen saturation, suggest that in the Cascavel Stream green algae growth was favored by high organic pollution level.

Necchi Jr. et al. (1994) reported a decrease in the number of species of Rhodophyta in stretches with organic pollution. The absence of Rhodophyta in site P3 confirms that this division is actually sensitive to intense organic pollution as previous studies have already demonstrated (Necchi Jr., 1993; Branco and Pereira, 2002).

The occurrence of Schizomeris leibleinii in the sampling site with the highest pollution level (P3) agrees with previous studies which have commonly reported the presence of the species in organic polluted environments (Necchi Jr. et al., 1994; Branco and Pereira, 2002). Several research works (Fjerdingstad, 1964; Necchi Jr. et al. 1994; Pereira and Branco, 2007), including our own, have indicated that $S$. leiblenii can be considered as a potential indicator of organic polluted waters.

Branco and Pereira (2002) suggested that the heterocytous Cyanophyta occur rather in environments with low pollution level, while the homocytous in environments with high pollution levels. Our results, particularly the exclusive presence of Tolypothrix distorta in stream stretches with lower pollution level and the occurrence of homocytous Cyanophyta (P. autumnale and $P$. retzii) in all sampling sites, agree with this assumption.

In summary, in this study macroalgal community structure was slightly affected by organic pollution, leading to an increase of the Chlorophyta species richness and percent cover associated with the absence of Rhodophyta in the highest polluted stretch. In addition, the analysis of the richness throughout the stream course showed that the highest values were found in its intermediate part, being partly in accordance with the RCC.

\section{Acknowledgements}

We are grateful to SANEPAR (Companhia de Saneamento do Paraná) for some laboratory analyses, to $\mathrm{CNPq}$ for doctorate scholarship to $\mathrm{CKP}$ and RAK, and research grant to CCZB. We greatly appreciated field work help provided by Durinézio J. Almeida, Marcos R. Barboza, and Cristiano M. Pereira. 


\section{References}

ALLAN, JD. and CASTILLO, MM. 2007. Stream Ecology: structure and function of running waters. 2nd ed. Netherlands: Springer. 436 p.

American Public Health Association - APHA, 1998. Standard Methods for the Examination of Water and Wastewater. 20th edition. Washington, DC: American Public Health Association. 1530 p.

BIGGS, BJF. 1989. Biomonitoring of organic pollution using periphyton, South Branch, Canterbury. New Zealand Journal of Marine and Freshwater Research, vol. 23, p. 263-274.

BORGES, FR. and NECCHI Jr., O. 2006. Patterns of spatial distribution in macroalgal communities from tropical lotic ecosystems. Revista Brasileira de Botânica, vol. 29, p. 669-680.

BRANCO, CCZ. and NECCHI Jr., O. 1996. Distribution of stream macroalgae in the eastern Atlantic Rainforest of São Paulo State, Southeastern Brazil. Algological Studies, vol. 333, p. 139-150.

BRANCO, CCZ., KRUPEK, RA. and PERES, CK. 2009a. Distribution of stream macroalgal communities from the mid-western region of Paraná State: importance of local scale variation. Brazilian Archives of Biology and Technology, vol. 52, no. 2, p. 379-386.

BRANCO, CCZ., KRUPEK, RA. and PERES, CK. 2009b. Seasonality of macroalgal communities in a subtropical drainage basin in Paraná State, Southern Brazil. Brazilian Journal of. Biology, vol. 68, no. 4, p. 741-749.

BRANCO, LHZ. and NECCHI Jr., O. 1997. Seasonality of macroalgae in three tropical drainage basins in São Paulo State, southeastern Brazil. Archiv für Hydrobiologie, vol. 141, p. 75-91.

BRANCO, LHZ. and PEREIRA, JL. 2002. Evaluation of seasonal dynamics and bioindication potential of macroalgal communities in a polluted tropical stream. Archiv für Hydrobiologie, vol. 155, p. 147-161.

CAMARGO, JA. and JIMENEZ, A. 2007. Ecological responses of epilithic diatoms and aquatic macrophytes to fish farm pollution in a Spanish river. Anales del Jardín Botánico de Madrid, vol. 64, no. 2, p. 213-219.

DELL'UOMO, A. 1991. Use of benthic macroalgae for monitoring rivers in Italy. In WHITTON, BA., ROTT, E. and FRIEDRICH, G. (eds.). Use of algae for monitoring rivers. Universität Innsbruck: Institut für Botanik. p. 129-137.

FELLOWS, CS., CLAPCOTT, JE., UDY, JW., BUNN, SE., HARCH, BD., SMITH. MJ. and DAVIES, PM. 2006. Benthic metabolism as an indicator of stream ecosystem health. Hydrobiologia, vol. 572, p. 71-87.
FJERDINGSTAD, E. 1964. Pollution of streams estimated by benthal phytomicro-organisms I. A saprobic system based on communities of organisms and ecological factors. International Review ges Hydrobiologie, vol. 49, p. 63-131.

HAMMER, O., HARPER, DAT. and RYAN, PD. 2001. Past: palaeontological statistics software package for education and data analysis. Palaeontologia Electronica, vol. 4, no. 1, p. 1-9.

HILL, BH., HERLIHY, AT., KAUFMANN, PR., STEVENSON, RJ., McCORMICK, FH. and JOHNSON, B. 2000. Use of periphyton assemblage data as an index of biotic integrity. Journal of North American Benthological Society, vol. 19, no. 1, p. 50-67.

HU, BF. and XIE, SL. 2006. Effect of seasonality on distribution of macroalgae in a stream system (Xin' an Spring) in Shanxi Province, North China. Journal of Integrative Plant Biology, vol. 48, no. 8, p. 889-896.

KREBS, CJ. 1989. Ecological methodology. New York: Harper Collins. 654 p.

KRUPEK, RA., BRANCO, CCZ. and PERES, CK. 2007. Distribuição ecológica das comunidades de macroalgas da bacia de drenagem do Rio das Pedras, região centro-sul do estado do Paraná, Sul do Brasil. Revista Brasileira de Botânica, vol. 30, no. 2, p. 173-182.

MAACK, R. 1981. Geografia Física do Estado do Paraná. 2. ed. Rio de Janeiro: Editora José Olympio. 450 p.

NECCHI Jr., O. 1993. Distribution and seasonal dynamics of Rhodophyta in the Preto River basin, Southeastern Brazil. Hydrobiologia, vol. 250, p. 81-90.

NECCHI Jr., O. and MOREIRA, JCL. 1995. Longitudinal distribution of macroalgae in two tropical lotic ecosystem from south-eastern Brazil. Archiv für Hydrobiologie, vol. 135, p. 113-128.

NECCHI Jr., O. and PASCOALOTO, D. 1993. Seasonal dynamics of macroalgal communities in the Preto River basin, São Paulo, Southeastern Brazil. Archiv für Hydrobiologie, vol. 129, p. 231-252.

NECCHI Jr., O., BRANCO, CCZ. and BRANCO, LHZ. 2000. Distribution of stream macroalgae in São Paulo State, Southeastern Brazil. Algological Studies, vol. 97, p. 43-57.

NECCHI Jr., O., BRANCO, LHZ and BRANCO, CCZ. 1995. Comparison of three techniques for estimating periphyton percent cover in bedrock streams. Archiv für Hydrobiologie, vol. 134, p. 393-402.

NECCHI Jr., O., BRANCO, LHZ. and DIP, MR. 1994. Uso de macroalgas para avaliação da poluição orgânica no Rio Preto, noroeste do estado de São Paulo. Anais da Academia Brasileira de Ciências, vol. 66, p. 359-371.

NECCHI Jr., O., DIP, MR. and GÓES, RM. 1991. Macroalgae of a stream in Southeastern Brazil: 
composition, seasonal variation and relation to physical and chemical variables. Hydrobiologia, vol. 213, p. 241-250.

PEREIRA, JL. and BRANCO, LHZ. 2007. Influência do nitrato e fosfato no crescimento de Schizomeris leibleinii Kützing (Chaetophorales, Chlorophyta). Acta Botanica Brasilica, vol. 21, no. 1, p. 155-162.

PERES, CK., BRANCO, CCZ. and KRUPEK, RA. 2008. Macroalgas de riachos da Serra da Prata, leste do Paraná, Sul do Brasil. Acta Botanica Brasilica, vol. 22, no. 2, p. 333-344.

RODERJAN, CV., GALVÃO, F., KUNIYOSHI, YS. and HATSCHBACH, GG. 2002. As unidades fitogeográficas do Estado do Paraná. Ciência \& Ambiente, vol. 24, p. 75-92.

ROSENBERG, DM. and RESH, VH. 1993. Freshwater biomonitoring and benthic macroinvertebrates. New York: Chapman and Hall. 488 p.

SHEATH, RG. and BURKHOLDER, J. 1985. Characteristics of softwater stream in Rhode Island II: composition and seasonal dynamics of macroalgae communities. Hydrobiologia, vol. 128, p. 109-118.

SHEATH, RG. and COLE, KM. 1992. Biogeography of stream macroalgae in North America. Journal of Phycology, vol. 28, p. 448-460.

SHEATH, RG., HAMILTON, PB., HAMBROOK, JA. and COLE, KM. 1989. Stream macroalgae of eastern boreal forest region of North America. Canadian Journal of Botany, vol. 67, p. 3553-3562.

SHEATH, RG., MORINSON, MO., KORCH, JE., KACZMAREZYK, D. and COLE, KM. 1986.
Distribuition of stream macroalgae in south-central Alasca. Hydrobiologia, vol. 135, p. 259-269.

SMITH, WS. and PETRERE Jr., M. 2000. Caracterização limnológica da bacia de drenagem do rio Sorocaba, São Paulo, Brasil. Acta Limnologica Brasiliensia, vol. 12, p. 15-27.

STRIEDER, MN., RONCHI, LH., STENERT, C., SCHERER, RT. and NEISS, UG. 2006. Medidas biológicas e índices de qualidade da água de uma microbacia com poluição urbana e de curtumes no Sul do Brasil. Acta Biologica Leopondensia, vol. 28, no. 1, p. 17-24.

VANNOTE, RL., MINSHALL, GW., CUMMINS, KW., SEDELL, JR. and GUSHING, E. 1980. The river continuum concept. Canadian Journal of Fisheries and Aquatic Sciences, vol. 37, p. 130-137.

VIDOTTI, EC. and ROLLEMBERG, MCE. 2004. Algas: da economia nos ambientes aquáticos à biorremediação e à química analítica. Química Nova, vol. 27, p. 139-145.

VIS, ML., Hudon, C., CATTANeO, A. and PINEL-ALLOUL, B. 1998. Periphyton as an indicator of water quality in the St. Lawrence River, Québec, Canada. Environmental Pollution, vol. 101, p. 13-24.

VIS, ML., SHEATH, RG., HAMBROOK, JA. and COLE, KM. 1994. Stream macroalgae of the Hawaiian islands: a preliminary study. Pacific Science, vol. 48, p. 175-187.

Received: 07 April 2010 Accepted: 27 September 2010 